Research Article

\title{
Do Intellectual Capital Elements Spur Firm Performance? Evidence from the Textile and Apparel Industry in China
}

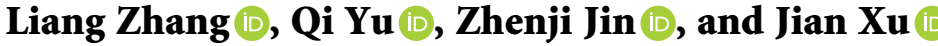 \\ School of Management, Qingdao Agricultural University, Qingdao 266109, China \\ Correspondence should be addressed to Zhenji Jin; zhenji12@aliyun.com and Jian Xu; xujiansword@163.com
}

Received 30 April 2021; Revised 18 May 2021; Accepted 20 May 2021; Published 27 May 2021

Academic Editor: Mohammad Yazdi

Copyright (c) 2021 Liang Zhang et al. This is an open access article distributed under the Creative Commons Attribution License, which permits unrestricted use, distribution, and reproduction in any medium, provided the original work is properly cited.

\begin{abstract}
This paper examines how investment in intellectual capital (IC) elements by textile and apparel companies improves firm performance measured in terms of profitability, market value, and productivity. The modified value-added intellectual coefficient (MVAIC) model is applied to measure IC. Using a panel of 35 Chinese textile and apparel companies for a six-year period (2013-2018), the results show that physical and human capitals are the strong factors that contribute to firm performance. In addition, relational capital negatively influences profitability and market value, and structural capital and innovation capital have a negative impact on employee productivity. We also find that the MVAIC model performs better in measuring IC than the original value-added intellectual coefficient (VAIC) model. This paper can provide some insights for corporate managers to enhance firm performance and gain competitive advantage by proper utilization of IC in traditional industries.
\end{abstract}

\section{Introduction}

The resource-based theory emphasizes the heterogeneity of firms' resources and the existence of capabilities. Nowadays, managing and upgrading knowledge resources determine the success of any organization [1-3]. In the knowledge economy, intellectual capital (IC) as an intangible resource can help a firm to generate economic returns and build competitive advantage along with tangibles [4-8].

The textile and apparel industry is traditionally laborintensive, and this old manufacturing industry has become a sunset industry with low added-value products because of low level of technological innovation [9]. It requires large input of water and energy in fabric production, which could bring serious damage to ecological environment by various pollutants. This industry is also one of the most important customer merchandise industries with a long supply chain from the distribution of fibers to end users or consumers [10]. Textile and apparel companies generally have tight connections with suppliers, manufacturers, intermediaries, and customers in the whole product life cycle [11]. In recent years, this industry is exposed to the increase in the price of raw materials such as cotton, which lowers the profits of manufacturers. In order to overcome some barriers, firms started to search a new way with production of high-tech and technically demanding textiles.

China's textile and apparel industry as the pillar of national economy accounts for about one-fifth of total production in the world [12]. Its comparative advantage in the global market is not obvious [13], and it is still at the low end of the global value chain [14]. In the face of fierce market competition, textile and apparel companies are forced to cut prices, which leads to lower profitability. In addition, there is an increasingly great demand for clothing and footwear products in China's domestic market, but there are not many internationally influential brands of domestic companies. Due to the outbreak of the novel coronavirus (COVID-19), the production and export of this industry experienced a great decrease from January to April in 2020 compared with the previous year [15]. The rising costs of domestic production, insufficient domestic and foreign demand, trade barriers, and other factors have led to the continuous decrease in industrial competitiveness [16-18]. Therefore, it is urgently important that this industry transform industrial structure from the energy-consuming pattern to the eco- 
environment-oriented pattern. Intangibles will play a significant role in this transformation, especially IC.

The objective of this paper is to explore empirically the impact of IC elements on firm performance, using China's textile and apparel companies as our selected sample. Following $\mathrm{Ge}$ and $\mathrm{Xu}$ [19], $\mathrm{Xu}$ and Liu [20], and Liu et al. [21], we use the modified value-added intellectual coefficient (MVAIC) model as a measure of IC in comparison with pulic's [22] original value-added intellectual coefficient (VAIC) model.

There are few studies that are conducted in the context of China, and the IC's impact in textile and apparel industry is not fully understood. In addition, empirical analysis in the current IC literature is still based on the original VAIC model by ignoring the role of relational capital (RC) and innovation capital (INC) in value creation. Therefore, this study contributes to the theoretical perspective by employing the MVAIC model with the inclusion of them. Finally, it might help managers of China's textile and apparel industry to enhance firm performance and gain their competitiveness through effective IC utilization.

In the remaining parts of the paper, a literature review is provided in Section 2. Section 3 develops the relevant hypotheses, followed by Section 4 detailing the methodology. Section 5 shows the empirical results, and Section 6 discusses these results. Finally, Section 7 is the conclusion.

\section{Literature Review}

2.1. IC Definition, Classification, and Measurement. There are many definitions of IC explained in the current IC literature. At the initial stage, Stewart [23] described IC as the tools of intangibles in creating wealth. It was defined as the set of all knowledge possessed by the employees and the company [24]. Additionally, Edvinsson and Malone [25] defined the difference between a firm's market value and book value as IC.

It is generally believed that there are three key areas, namely, human capital (HC), structural capital (SC), and RC constitute IC [26-36]. HC includes employees and their attributes such as knowledge, experience, and skills [37]. SC includes firm's strategies, databases, information management, intellectual property, corporate culture, and the like [24]. RC deals with internal and external relationships with various stakeholders [38].

Several methods have been proposed to measure IC. Among them, the VAIC model explains the efficiency of value creation in any organization depending on capital employed efficiency (CEE), human capital efficiency (HCE), and structural capital efficiency (SCE). Its simplicity and data availability lead to the wide use of this method in measuring IC. However, it also suffers from several weaknesses. First, this model only measures past IC based on the historical data from financial reports. Second, the synergy effects between different forms of tangible and intangible assets are not taken into account in this model [39]. Third, it neglects the existence of RC and INC that is considered as the measures of the efficiency of IC [40]. Therefore, we will employ the MVAIC model to systematically measure IC in this paper.
Figure 1 demonstrates the classification of a company's assets.

2.2. IC and Firm Performance. Although much research has been devoted to developed countries, emerging markets have drawn the attention of scholars in the current IC research $[6,8,19-21,29-33,35,36,39-42]$. In addition, most studies use a three-dimensional framework to analyze IC performance based on the original VAIC model. Table 1 shows an overview of the relationship between IC and firm performance, but the results are not consistent.

\section{Hypotheses Development}

CEE refers to all necessary financial funds and physical capital in the pulic's [22] VAIC model. Researchers such as Chen et al. [40], Tandon et al. [55], Dzenopoljac et al. [56], and Poh et al. [57] documented a positive impact of CEE on organizational performance. Taking agricultural enterprises as the sample, $\mathrm{Xu}$ and Wang [49] found a positive relationship between CEE and firms' profitability and productivity. A study on commercial banks by Oppong and Pattanayak [58] found CEE to be positive and significant with ATO and employee productivity (EP). In the light of these arguments, the study hypothesizes the following.

Hypothesis 1 (H1). Physical capital can enhance firm performance in China's textile and apparel industry.

Concerning HC, Nimtrakoon [27] found that $\mathrm{HC}$ contributes most to financial performance (margin ratio and ROA). Similarly, Xu and Wang [5], Xu et al. [32], and Xu and $\mathrm{Li}[33,35]$ confirmed this positive relationship. Using the VAIC model, Smriti and Das [59] in their study observed that $\mathrm{HC}$ positively affects firm productivity while its impact on profitability is not significant in Indian listed companies. Also, a study in an emerging economy (Ghana) by Oppong et al. [6] showed that HCE positively affects firm productivity. Conversely, Kasoga [52] documented this negative relationship using ROA, ATO, sales growth, and Tobin's Q as performance indicators. Therefore, the current study hypothesizes the following.

Hypothesis 2 ( $\mathrm{H} 2)$. HC can enhance firm performance in China's textile and apparel industry.

The findings of Kasoga [52] revealed a significant and positive relationship between SCE and financial performance. In the context of Russia, Andreeva and Garanina [60] pointed out that SC contributes to the performance of manufacturing companies. Likewise, Alipour [61], Soriya and Narwal [62], and Onyekwelu et al. [63] found that SCE does drive the firms' performance. Examining the association between IC and productivity, Oppong and Pattanayak [58] found that SC component plays a role in improving the productivity of public and private banks. Liu et al. [21] argued that SC has the strongest impact on financial competitiveness in China's renewable energy sector. Therefore, the third hypothesis is as follows. 


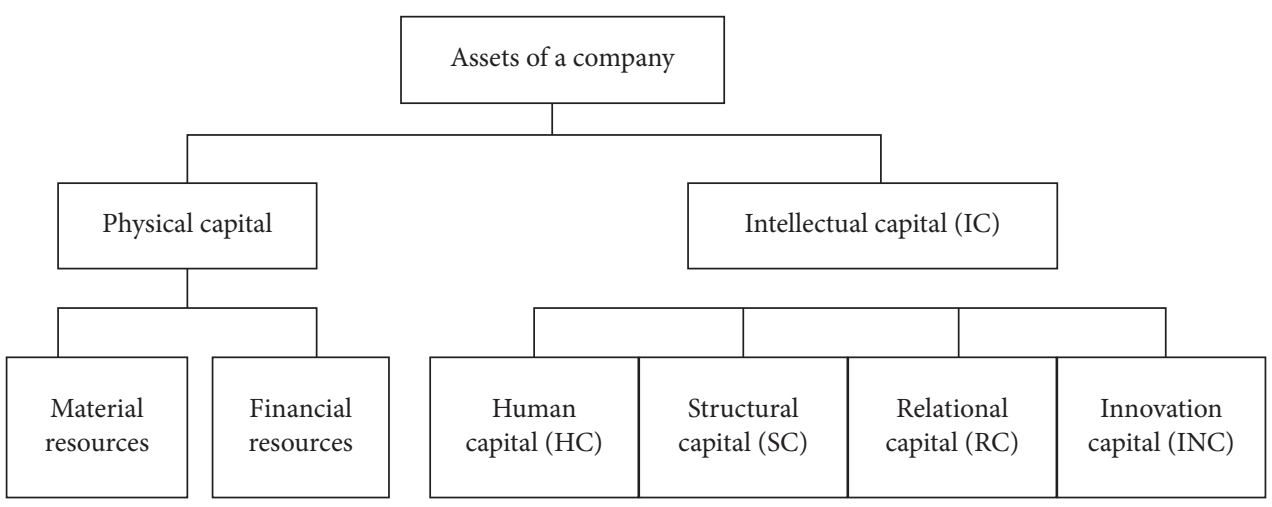

Figure 1: Company assets and IC classification of this paper.

TABLE 1: Representative studies on IC and firm performance.

\begin{tabular}{|c|c|c|c|c|c|}
\hline Author & $\begin{array}{c}\text { IC } \\
\text { measurement }\end{array}$ & Dependent variable & Sample & Data source & Main findings \\
\hline Kweh et al. [41] & Ratios & Operating performance & $\begin{array}{l}\text { Life insurance firms in } \\
\text { Taiwan and China }\end{array}$ & $\begin{array}{l}\text { Financial } \\
\text { reports }\end{array}$ & $\begin{array}{c}\mathrm{HC} \text { is positively linked to } \\
\text { operating performance, } \\
\text { while SC is negatively } \\
\text { related. }\end{array}$ \\
\hline $\begin{array}{l}\text { Bhatia and } \\
\text { Aggarwal [42] }\end{array}$ & VAIC & $\begin{array}{l}\text { Return on assets (ROA) and } \\
\text { return on net worth }\end{array}$ & $\begin{array}{c}\text { Software companies in } \\
\text { India }\end{array}$ & PROWESS & $\begin{array}{l}\text { All IC components are } \\
\text { positively related with } \\
\text { financial performance. }\end{array}$ \\
\hline $\begin{array}{l}\text { Nimtrakoon } \\
\text { [27] }\end{array}$ & MVAIC & $\begin{array}{l}\text { Market-to-book ratio }(\mathrm{MB}) \\
\text { margin ratio, and } \mathrm{ROA}\end{array}$ & $\begin{array}{c}\text { Technology firms in the } \\
\text { ASEAN }\end{array}$ & $\begin{array}{l}\text { Five stock } \\
\text { exchanges }\end{array}$ & $\begin{array}{c}\text { Physical capital and } \mathrm{HC} \\
\text { are the most influential } \\
\text { factors, while SC and RC } \\
\text { have less impact. }\end{array}$ \\
\hline $\begin{array}{l}\text { Dženopoljac } \\
\text { et al. [43] }\end{array}$ & VAIC & $\begin{array}{l}\text { ROA, return on equity (ROE), } \\
\text { return on invested capital, } \\
\text { profitability, and asset turnover } \\
\text { ratio (ATO) }\end{array}$ & $\begin{array}{c}\text { Information } \\
\text { communication } \\
\text { technology companies } \\
\text { in Serbia }\end{array}$ & $\begin{array}{l}\text { Serbian Agency } \\
\text { for Business } \\
\text { Registers }\end{array}$ & $\begin{array}{l}\text { Only physical capital has a } \\
\text { significant impact on } \\
\text { financial performance. }\end{array}$ \\
\hline $\begin{array}{l}\text { Meles et al. } \\
{[44]}\end{array}$ & VAIC & ROA and ROE & $\begin{array}{c}\text { Commercial banks in } \\
\text { US }\end{array}$ & $\begin{array}{c}\text { Bankscope } \\
\text { Bureau Van Dijk }\end{array}$ & $\begin{array}{l}\mathrm{HC} \text { has a positive impact } \\
\text { on financial performance. }\end{array}$ \\
\hline $\begin{array}{l}\text { Ozkan et al. } \\
\text { [45] }\end{array}$ & VAIC & $\mathrm{ROA}$ & Banks in Turkey & $\begin{array}{l}\text { Financial } \\
\text { reports }\end{array}$ & $\begin{array}{c}\text { Physical capital and } \mathrm{HC} \\
\text { positively affect financial } \\
\text { performance. }\end{array}$ \\
\hline $\begin{array}{l}\text { Smriti and Das } \\
{[46]}\end{array}$ & VAIC & $\mathrm{ROA}, \mathrm{MB}$, and ATO & $\begin{array}{l}\text { Pharmaceutical and } \\
\text { drug companies in } \\
\text { India }\end{array}$ & CMIE & $\begin{array}{l}\text { Physical capital and SC } \\
\text { determine business } \\
\text { performance. }\end{array}$ \\
\hline $\mathrm{Xu}$ et al. [47] & VAIC & ROA and ROE & $\begin{array}{l}\text { Environmental } \\
\text { protection companies } \\
\text { in China }\end{array}$ & $\begin{array}{l}\text { Financial } \\
\text { reports }\end{array}$ & $\begin{array}{c}\mathrm{HC} \text { and SC exert a } \\
\text { positive impact, while } \\
\text { INC does not have an } \\
\text { impact. }\end{array}$ \\
\hline $\begin{array}{l}\text { Chowdhury } \\
\text { et al. [48] }\end{array}$ & VAIC & $\mathrm{ATO}, \mathrm{ROA}$, and ROE & $\begin{array}{l}\text { Textile firms in } \\
\text { Bangladesh }\end{array}$ & $\begin{array}{l}\text { Financial } \\
\text { reports }\end{array}$ & $\begin{array}{c}\text { Tangible capital and SC } \\
\text { have a positive impact, } \\
\text { whereas the impact of HC } \\
\text { is not significant. }\end{array}$ \\
\hline $\begin{array}{l}\text { Tiwari and } \\
\text { Vidyarthi [29] }\end{array}$ & MVAIC & $\mathrm{ROA}$ and $\mathrm{ROE}$ & Banks in India & PROWESS & $\begin{array}{l}\mathrm{HC} \text { and SC show a } \\
\text { positive linkage with } \\
\text { banks' performance. }\end{array}$ \\
\hline $\begin{array}{l}\mathrm{Xu} \text { and Wang } \\
{[49]}\end{array}$ & VAIC & $\begin{array}{c}\text { Earnings before interest and } \\
\text { taxes (EBIT), ROA, ROE, and } \\
\text { ATO }\end{array}$ & $\begin{array}{c}\text { Agricultural companies } \\
\text { in China }\end{array}$ & CSMAR & $\begin{array}{l}\text { Physical and human } \\
\text { capitals impact firm } \\
\text { performance. }\end{array}$ \\
\hline $\mathrm{Xu}$ et al. [32] & MVAIC & ROA and ROE & $\begin{array}{l}\text { Manufacturing } \\
\text { companies in China }\end{array}$ & RESSET & $\begin{array}{c}\mathrm{HC} \text { and SC positively } \\
\text { affect firm performance, } \\
\text { while RC exerts a negative } \\
\text { impact. }\end{array}$ \\
\hline Yao et al. [50] & $\begin{array}{l}\text { VAIC and } \\
\text { MVAIC }\end{array}$ & $\begin{array}{c}\text { ROA, net operating margin, and } \\
\text { ATO }\end{array}$ & $\begin{array}{c}\text { Financial institutions in } \\
\text { Pakistan }\end{array}$ & $\begin{array}{l}\text { Financial } \\
\text { reports }\end{array}$ & $\begin{array}{l}\text { HC can increase firm } \\
\text { performance significantly. }\end{array}$ \\
\hline
\end{tabular}


TABLE 1: Continued.

\begin{tabular}{|c|c|c|c|c|c|}
\hline Author & $\begin{array}{c}\text { IC } \\
\text { measurement }\end{array}$ & Dependent variable & Sample & Data source & Main findings \\
\hline $\begin{array}{l}\text { Bansal and } \\
\text { Singh [51] }\end{array}$ & VAIC & ROA and ATO & $\begin{array}{l}\text { Software companies in } \\
\text { India }\end{array}$ & PROWESS & $\begin{array}{l}\text { Intangible capital has the } \\
\text { greatest impact. }\end{array}$ \\
\hline Costa et al. [34] & MVAIC & ROA & $\begin{array}{l}\text { Hospitality and tourism } \\
\text { industry in Portuguese }\end{array}$ & SABI & $\begin{array}{c}\text { CEE and HCE have a } \\
\text { positive impact, while } \\
\text { SCE presents a negative } \\
\text { impact. }\end{array}$ \\
\hline Kasoga [52] & VAIC & $\begin{array}{c}\text { ROA, ATO, sales growth (SG), } \\
\text { and Tobin's Q }\end{array}$ & $\begin{array}{c}\text { Service and } \\
\text { manufacturing firms in } \\
\text { Tanzania }\end{array}$ & $\begin{array}{l}\text { Financial } \\
\text { reports }\end{array}$ & $\begin{array}{l}\text { A positive impact of SC } \\
\text { and a negative impact of } \\
\text { physical and human } \\
\text { capitals are observed. }\end{array}$ \\
\hline $\begin{array}{l}\text { Gupta and } \\
\text { Raman [53] }\end{array}$ & MVAIC & ROA & $\begin{array}{l}\text { Information technology } \\
\text { (IT) and } \\
\text { pharmaceutical firms in } \\
\text { India }\end{array}$ & $\begin{array}{l}\text { Financial } \\
\text { reports and S\&P } \\
\text { Global Capital } \\
\text { IQ }\end{array}$ & $\begin{array}{l}\text { Physical capital, HC, RC, } \\
\text { and process capital have } \\
\text { an impact on ROA. }\end{array}$ \\
\hline $\begin{array}{l}\text { Neves and } \\
\text { Proença [54] }\end{array}$ & VAIC & $\begin{array}{l}\text { ROA, ROE, and net interest } \\
\text { margin }\end{array}$ & Banks in Portugal & $\begin{array}{l}\text { Financial } \\
\text { reports }\end{array}$ & $\begin{array}{l}\text { All IC components } \\
\text { influence banks' } \\
\text { performance. }\end{array}$ \\
\hline $\mathrm{Xu}$ and Liu [8] & IC index & $\begin{array}{l}\text { Earnings before interest, taxes, } \\
\text { depreciation and amortization } \\
\text { (EBITDA), net profit margin, } \\
\text { gross profit margin, return on } \\
\text { investment, ROA, and ROE }\end{array}$ & $\begin{array}{l}\text { Manufacturing } \\
\text { companies in China }\end{array}$ & $\begin{array}{l}\text { CSMAR and } \\
\text { RESSET }\end{array}$ & $\begin{array}{l}\text { IC is positively related to } \\
\text { all performance indicators } \\
\text { except EBITDA. }\end{array}$ \\
\hline
\end{tabular}

Hypothesis 3 (H3). SC can enhance firm performance in China's textile and apparel industry.

With regard to RC, Barkat et al. [64] conducted a survey in large textile companies in Pakistan and reported that three dimensions of IC including $\mathrm{HC}, \mathrm{RC}$, and INC have a direct effect on organizational performance. Xu and Wang [5] found it to be the most influential factor to financial performance and sustainable growth. The empirical evidence from Indian pharmaceutical companies by Gupta et al. [65] confirmed a correlation between RC and firm profitability. A study on manufacturing firms by $\mathrm{Xu}$ and $\mathrm{Li}$ [35] similarly recorded a strong association between RC and profitability and productivity for a fiveyear period (2012-2016). Xu et al. [66] also documented a positive relationship between RC and corporate sustainable growth. Therefore, we propose the following hypothesis.

Hypothesis $4(\mathrm{H} 4)$. RC can enhance firm performance in China's textile and apparel industry.

INC refers to the skills and capabilities that a company needs to create new products and services and to place them promptly on the market [67]. It can drive wealth generation, economic development, and human well-being [68, 69]. Chen et al. [40] claimed that INC has a positive effect in the MB, ROA, and SG models. The findings of Lu et al. [70] found that INC positively enhances firm performance of Chinese firms that accepted Venture-Capital Syndication funding. Bayraktaroglu et al. [71] declared that INC directly leads to the increase in firms' productivity. As $\mathrm{Ni}$ et al. [72] revealed, INC might be beneficial for firms to improve firm value because firms need to search for new ideas to achieve innovation. Therefore, we propose the following hypothesis.
Hypothesis 5 (H5). INC can enhance firm performance in China's textile and apparel industry.

\section{Methodology}

4.1. Data Source. This paper is based on the secondary data that are obtained from the China Stock Market and Accounting Research (CSMAR) database. The sample includes textile and apparel companies listed on the Shanghai and Shenzhen stock exchanges from 2013 to 2018. After screening and removing companies with missing information, companies with debt ratio great than 1, and special treatment (ST) companies, an unbalanced panel of 35 companies with 165 observations has been left for estimation.

\subsection{Variables}

(1) Dependent Variables. Firm performance (PER) is measured in three aspects: profitability, market value, and productivity. ROA (measured by the ratio of net income to average total assets) and ROE (measured by the ratio of net income to average shareholders' equity) measure the profitability of the companies. $\mathrm{MB}$ is used to measure market value of the companies. EP is calculated as the ratio of pretax income (unit: 10,000 yuan) to the number of employees. It is included as a measure of productivity in the IC literature [40, 58, 73-76].

(2) Independent Variables. This study measures the efficiency of IC components by using the MVAIC model. The MVAIC model is a sum of five components: CEE, HCE, SCE, relational capital efficiency 
(RCE), and innovation capital efficiency (INCE). They are calculated as follows:

$$
\begin{aligned}
& \mathrm{VA}=\text { total revenues }- \text { total expenses }+ \text { employee } \\
& \text { expenditures } \\
& \mathrm{CEE}=\mathrm{VA} / \text { book value of net assets } \\
& \mathrm{HCE}=\mathrm{VA} / \text { all employee expenditures } \\
& \mathrm{SCE}=(\mathrm{VA} \text { - all employee expenditures }) / \mathrm{VA} \\
& \mathrm{RCE}=\text { marketing, selling, and advertising expenses/ } \\
& \mathrm{VA} \\
& \mathrm{INCE}=\mathrm{R} \& \mathrm{D} \text { expenses/VA }
\end{aligned}
$$

(3) Control Variables. Firm size (SIZE) is the natural log of total assets. Debt ratio (LEV) is defined as total liabilities divided by total assets. Firm age (AGE) is the natural log of the number of years since the setup of the company. The growth rate of gross domestic product (GDP) is used to control external influences. Additionally, a year dummy (YEAR) is also included in the models.
TABle 2: Descriptive statistics.

\begin{tabular}{lccccc}
\hline Variable & Mean & Median & Max & Min & SD \\
\hline ROA & 0.0427 & 0.0461 & 0.2178 & -0.5645 & 0.0753 \\
ROE & 0.0650 & 0.0654 & 0.5104 & -0.8789 & 0.1267 \\
MB & 2.3734 & 1.7364 & 33.3767 & 0.3406 & 2.8990 \\
EP & 7.8857 & 5.0915 & 76.8660 & -121.3850 & 19.8886 \\
CEE & 0.2448 & 0.2609 & 0.6603 & -1.2371 & 0.1894 \\
HCE & 1.8697 & 1.6861 & 6.3110 & -5.1907 & 1.3439 \\
SCE & 0.4236 & 0.4208 & 7.7953 & -4.0805 & 0.7785 \\
RCE & 1.6619 & 1.7038 & 14.8287 & -112.7872 & 9.2253 \\
INCE & 0.0715 & 0.0687 & 0.8335 & -1.5822 & 0.1637 \\
SIZE & 22.0108 & 21.8336 & 25.0489 & 19.0976 & 1.0942 \\
LEV & 0.3512 & 0.3225 & 0.7598 & 0.0796 & 0.1638 \\
AGE & 2.7079 & 2.7081 & 3.2189 & 1.9459 & 0.2871 \\
GDP & 0.0696 & 0.068 & 0.078 & 0.066 & 0.0040 \\
\hline
\end{tabular}

4.3. Models. The panel models are estimated to examine the effect of different IC elements on firm performance. Model (1) is based on the original VAIC method, and Model (2) is on the basis of the MVAIC method including RC and INC. The panel model specifications are as follows:

$$
\begin{aligned}
\mathrm{PER}_{i, t}= & \beta_{0}+\beta_{1} \mathrm{CEE}_{i, t}+\beta_{2} \mathrm{HCE}_{i, t}+\beta_{3} \mathrm{SCE}_{i, t}+\beta_{4} \mathrm{SIZE}_{i, t} \\
& +\beta_{5} \mathrm{LEV}_{i, t}+\beta_{6} \mathrm{AGE}_{i, t}+\beta_{7} \mathrm{GDP}_{i, t}+\sum \mathrm{YEAR}+\varepsilon_{i, t}, \\
\mathrm{PER}_{i, t}= & \beta_{0}+\beta_{1} \mathrm{CEE}_{i, t}+\beta_{2} \mathrm{HCE}_{i, t}+\beta_{3} \mathrm{SCE}_{i, t}+\beta_{4} \mathrm{RCE}_{i, t} \\
& +\beta_{5} \mathrm{INCE}_{i, t}+\beta_{6} \mathrm{SIZE}_{i, t}+\beta_{7} \mathrm{LEV}_{i, t}+\beta_{8} \mathrm{AGE}_{i, t}+\beta_{9} \mathrm{GDP}_{i, t}+\sum \mathrm{YEAR}+\varepsilon_{i, t},
\end{aligned}
$$

where $i$ stands for the individual firm; $t$ stands for the year; $\beta$ is the presumed parameter; and $\varepsilon$ is the measurement error term.

\section{Results}

5.1. Descriptive Statistics. Descriptive statistics are depicted in Table 2. In the observed period (2013-2018), it can be noticed that profitability, measured by ROA and ROE, has a mean score of 0.0427 and 0.0650 , respectively. The high value of MB implies that on average, market value of textile and apparel companies is higher than their book value. EP has a mean of 7.8857 with a maximum of 76.8660 and a minimum of -121.3850 . An increase in EP means that employees make more contribution to the firm. The average CEE in our sample is 0.2448 . As for IC elements, IC performance of companies in textile and apparel sector mainly depends on $\mathrm{HC}$ and RC. It is worth noticing that the standard deviations of HCE and RCE are higher. INC seems to create the smallest amount of value over the study period. Companies with low level of R\&D expense are more likely to restrict their innovative ability of new product development and patent application, which will lead to low competitiveness and intangible assets. Also, the average ratio of total leverage is about $35 \%$. The mean value of SIZE and AGE is 22.0108 and 2.7079 , respectively.
5.2. Correlation Analysis. Table 3 shows the results of correlation analysis. The results show that ROA and ROE are significantly positively correlated with CEE, HCE, and RCE. $\mathrm{MB}$ is negatively correlated with CEE, HCE, and RCE. EP proxy used for productivity is positively correlated with $\mathrm{CEE}, \mathrm{HCE}$, and RCE. In addition, the variance inflation factor (VIF) values are less than 10, indicating that multicollinearity is not a major issue.

5.3. Regression Results. Regression results are shown in Table 4. The Hausman tests indicate that the fixed effects model is appropriate in estimating the results of ROA, ROE, and $\mathrm{MB}$, and the random effects model is suitable when EP is the dependent variable. It is noticeable that the MVAIC model has higher adjusted $R^{2}$ values with ROA, ROE, and $\mathrm{MB}$ being dependent variables. However, for EP, the adjusted $R^{2}$ value slightly decreases in the MVAIC model. On the whole, the MVAIC model is more applicable to measure IC than the original VAIC model.

When ROA and ROE are the dependent variables, CEE and HCE play an important role in increasing the profits of textile and apparel companies. SCE exerts a positive impact on only the ROE indicator. However, RCE is found to negatively affect the profitability in this traditional industry. INC has no significant impact on profitability indicators. LEV is negatively associated with ROA and ROE. 


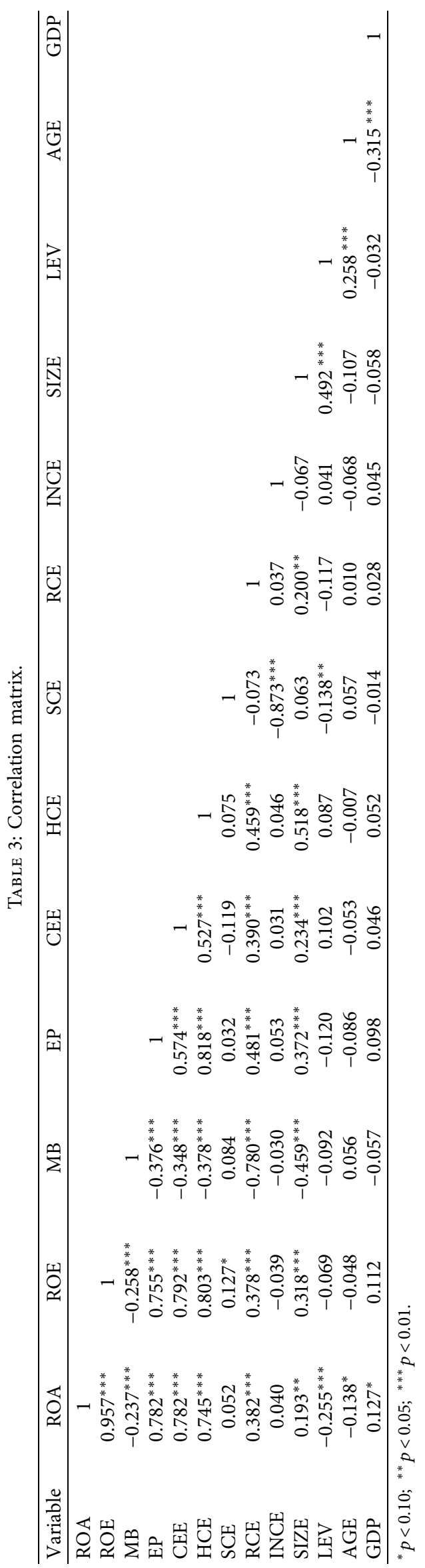




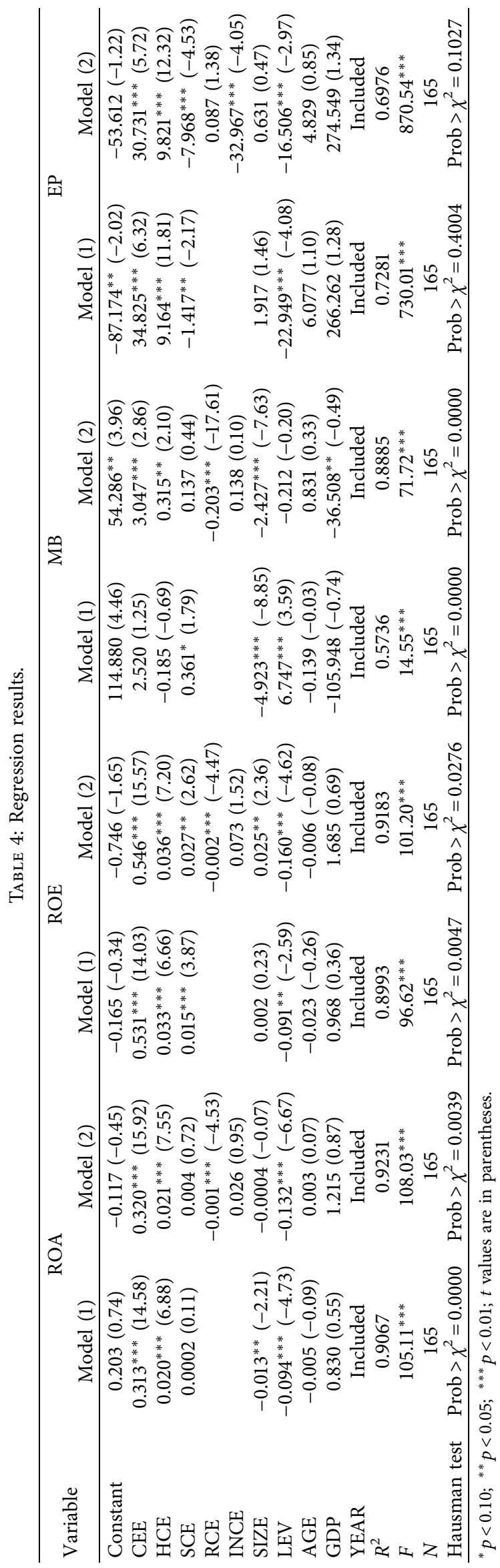


TABLE 5: Summary of regression results.

\begin{tabular}{lcccccccc}
\hline \multirow{2}{*}{ IC components } & \multicolumn{4}{c}{ VAIC model } & \multicolumn{4}{c}{ MVAIC model } \\
& ROA & ROE & MB & EP & ROA & ROE & MB & + \\
Physical capital & + & + & Insignificant & + & + & + & + \\
HC & + & + & Insignificant & + & + & + & + \\
SC & Insignificant & + & + & - & Insignificant & + & Insignificant \\
RC & N/A & N/A & N/A & N/A & - & - & - & Insignificant \\
INC & N/A & N/A & N/A & N/A & Insignificant & Insignificant & Insignificant \\
\hline
\end{tabular}

Regarding the variable MB, physical and human capitals positively influence MB in the MVAIC model. The impact of two IC elements (i.e., SC and INC) is not significant while $\mathrm{RC}$ has a negative and significant impact, which indicates that investors do not consider the values of IC in their decision. Pal and Soriya [77] found that IC does not help Indian textile companies to be more competitive in the increasingly dynamic environment.

In case of productivity measured by EP, physical and human capitals have a positive impact while structural and innovation capitals have a negative impact in the selected companies. The results are inconsistent with Oppong and Pattanayak [58] who stated that CEE is the only component that has a positive impact on EP and Phusavat et al. [73] and Bontis et al. [76] who concluded that human resources positively affect EP.

\section{Discussion}

Table 5 shows the summary of regression analysis in our study. From the results, it can be concluded that physical assets and $\mathrm{HC}$ are the most influential factors in improving the performance of Chinese textile and apparel companies.

Physical capital has the greatest influence on all performance indicators. Textile and apparel companies belong to manufacturing industry and traditionally depend on machinery and equipments. The findings are in line with $\mathrm{Ge}$ and $\mathrm{Xu}$ [19], $\mathrm{Xu}$ and Liu [20], $\mathrm{Xu}$ and Wang [31], and $\mathrm{Xu}$ and $\operatorname{Li}[33,35]$. However, in the Industry 4.0 era, such companies are required to achieve their industrial transformation. It is necessary for Chinese textile and apparel companies to increase investment in fixed assets and speed up the pace of upgrading equipment in order to gain international competitiveness under complex environment [17].

Table 5 shows that the better the $\mathrm{HC}$ of a firm is, the better its performance is. Although textile and apparel industry creates huge amount of jobs, most companies are still difficult to attract and retain high-quality employees. It should be pointed out that globally about $80 \%$ of workers are women in this industry [78]. The lack of training and education is a primary challenge the textile and apparel companies face in sustainable development [10].

As for SC, a survey conducted by Malinowska-Olszowy [67] showed that textile and apparel industry does not pay attention to the special role of intellectual property, especially patents. These may become a source of success for innovative textile and apparel manufacturers. In addition, the use of IT can improve corporate responsiveness and increase operational flexibility. Andersen and Segars [79] concluded that investment in IT has an indirect impact on performance enhancement in the US textile and apparel industry. Innovation in information and communications technology (ICT) and logistics technology is also needed in this sector that focuses on a mass production [80]. In China's economic transformation, such companies have begun to realize the salient importance of corporate culture, routines, processes, and technology.

$\mathrm{RC}$ seems to become a detrimental factor to firm performance improvement. However, the increasing interdependency of supply chain in this sector emphasizes stronger partnership-based alliances, thus reducing production costs [81]. In an emerging market (Vietnam), the best selection of suitable suppliers in this sector has been the concern of many practitioners that is affected by many unpredictable and uncertain issues [82]. Textile and apparel companies should determine the best supplier selection based on sourcing country, organization features (i.e., relationship, capability, and company's image) and performance metrics (i.e., quality, costs, delivery, and service) [83].

INC is not observed to stimulate firm performance in China's textile and apparel industry. In China, brand counterfeiting and imitation are serious, and most companies' revenue depends mainly on processing without automation or robots [16]. Malinowska-Olszowy [84] found that the poor performance of textile and apparel companies in Poland is caused by lack of introducing innovations. In Vietnam, undeveloped technology is a huge barrier to productivity improvement of this sector [85]. However, technology innovation ability in this industry has been improving since 2005 [9]. Furthermore, production time and reaction to trends are greatly shortened in this industry [86], which requires brand designers to have more innovative and novel ideas.

\section{Conclusions}

The study measures the impact of IC elements on firm performance on a sample of 35 textile and apparel companies listed over a period of 6 years (2013-2018). The MVAIC method is applied to measure the efficiency of IC, and firm performance is measured through ROA, ROE, MB, and EP. The results show that the MVAIC model is more appropriate in IC measurement than the conventional VAIC model of Pulic [22]. Regarding IC elements, HC exerts a positive impact on firm performance whereas SC and INC have a negative impact on only employee productivity. RC is 
found to negatively influence profitability and market valuation. In addition, physical capital is the most influencing contributor to firm performance improvement.

This study has several valuable implications. Firstly, management should incorporate IC strategies into their business strategies, effectively manage the level of IC, and make reasonable investments in each IC elements. Secondly, employees should get sufficient training to grasp the latest innovative technology and procedures applied in their production. Thirdly, corporate managers should also pay attention to SC, RC, and INC because they are also which drive firm performance in China's economic transformation. More importantly, they should develop new design concept and conduct more international cooperation and exchanges, thus improving firm profitability. In addition, these companies need to adopt green technology and develop new ecological protection products. They should also implement enterprise resource plan (ERP) system and computer integrated manufacture system (CIMS) to realize great-leap-forward development and upgrade industrial structure. Finally, the government should create a more favorable external environment, establish the industry management system, and provide more policy supports for $\mathrm{R} \& \mathrm{D}$ activities.

The current study has some limitations that should be addressed for future research. First, the research is restricted to textile and apparel companies, and future studies may be extended to other business industries. Second, more countries should be included in the future. Besides that, future studies may consider more variables in assessing IC toward firm performance.

\section{Data Availability}

The data used to support the findings of this study are available from the corresponding author upon request.

\section{Conflicts of Interest}

The authors declare that they have no conflicts of interest.

\section{Acknowledgments}

The authors would like to thank Prof. Mohammad Yazdi (Lead Editor) for his useful comments on earlier drafts. This research was supported by the Social Science Planning Research Program of Shandong Province (grant no. 18CKJJ01), the Scientific Research Project of Qingdao Agricultural University (grant nos. 6611114Q016 and 661118703), the Scientific Research Foundation for HighLevel Talents of Qingdao Agricultural University (grant no. 6631120701), and the Postgraduate Innovation Program of Qingdao Agricultural University (grant no. NYCX20011).

\section{References}

[1] L. Namdarian, A. Sajedinejad, and S. Bahanesteh, "The impact of knowledge management on organizational performance: a structural equation modeling study," $A D$-minister, vol. 37, no. 37, pp. 85-108, 2020.
[2] M. Chopra and V. Gupta, "Linking knowledge management practices to organizational performance using the balanced scorecard approach," Kybernetes, vol. 49, no. 1, pp. 88-115, 2020.

[3] M. S. Khan, P. Saengon, S. Charoenpoom, H. Soonthornpipit, and D. Chongcharoen, "The impact of organizational learning culture, workforce diversity and knowledge management on innovation and organization performance: a structural equation modeling approach," Human Systems Management, vol. 40, no. 1, pp. 103-115, 2021.

[4] C. M. Jardon, "The use of intellectual capital to obtain competitive advantages in regional small and medium enterprises," Knowledge Management Research \& Practice, vol. 13, no. 4, pp. 486-496, 2015.

[5] J. Xu and B. Wang, "Intellectual capital, financial performance and companies' sustainable growth: evidence from the Korean manufacturing industry," Sustainability, vol. 10, no. 12, p. $4651,2018$.

[6] G. K. Oppong, J. K. Pattanayak, and M. Irfan, "Impact of intellectual capital on productivity of insurance companies in Ghana," Journal of Intellectual Capital, vol. 20, no. 6, pp. 763-783, 2019.

[7] M. A. I. Cisneros, F. H. Perlines, and M. R. García, "Intellectual capital, organisational performance and competitive advantage," European Journal of International Management, vol. 14, no. 6, pp. 976-998, 2020.

[8] J. Xu and F. Liu, "Nexus between intellectual capital and financial performance: an investigation of Chinese manufacturing industry," Journal of Business Economics and Management, vol. 22, no. 1, pp. 217-235, 2021.

[9] H. F. Zhu, M. L. Huang, and Z. Zheng, "Research on the technology innovation ability of textile and apparel industry," Advanced Materials Research, vol. 627, pp. 609-612, 2013.

[10] F. Jia, S. Y. Yin, L. J. Chen, and X. W. Chen, "The circular economy in the textile and apparel industry: a systematic literature review," Journal of Cleaner Production, vol. 259, Article ID 120728, 2020.

[11] W. C. A. Chu, M. H. E. Chan, J. Cheung, and H.-O. Nguyen, "Looking back to look forward: setting future research agenda for international business in textiles and clothing industry," Journal of International Logistics and Trade, vol. 17, no. 1, pp. 21-32, 2019.

[12] C.-K. Lau, K.-M. To, Z. Zhang, and J. Chen, "Determinants of competitiveness: observations in China's textile and apparel industries," China \& World Economy, vol. 17, no. 2, pp. 45-64, 2009.

[13] H. S. Karaalp and N. D. Yilmaz, "Comparative advantage of textiles and clothing: evidence for Bangladesh, China, Germany and Turkey," Fibres \& Textiles in Eastern Europe, vol. 21, no. 1, pp. 14-17, 2013.

[14] M.-Y. Huang and X.-H. Deng, "Empirical analysis on the driving factors of China's textile and garment industry transformation and upgrading-based on quarterly panel data analysis of listed companies," Journal of Technical Economics \& Management, vol. 39, no. 9, pp. 118-123, 2018, in Chinese.

[15] S. Chakraborty and M. C. Biswas, "Impact of COVID-19 on the textile, apparel and fashion manufacturing industry supply chain: case study on a ready-made garment manufacturing industry," Journal of Supply Chain Management, Logistics and Procurement, vol. 3, no. 2, pp. 181-199, 2020.

[16] R. Y. Wang, "Analysis and research on innovation motivation and ability of listed companies in textile and garment 
industry," Shandong Textile Economy, vol. 37, no. 6, pp. 5-7, 2020, in Chinese.

[17] Z. Guan, Y. Xu, H. Jiang, and G. Jiang, "International competitiveness of Chinese textile and clothing industry-a diamond model approach," Journal of Chinese Economic and Foreign Trade Studies, vol. 12, no. 1, pp. 2-19, 2019.

[18] W. Chen, "Thoughts on the upgrading and development of China's textile and garment industry-based on the development of textile industry for reform and opening-up in the past 40 years," Review of Economic Research, vol. 40, no. 61, pp. 75-80, 2018, in Chinese.

[19] F. L. Ge and J. Xu, "Does intellectual capital investment enhance firm performance? Evidence from pharmaceutical sector in China," Technology Analysis \& Strategic Management, vol. 33, pp. 1-16, 2020.

[20] J. Xu and F. Liu, "The impact of intellectual capital on firm performance: a modified and extended VAIC model," Journal of Competitiveness, vol. 12, no. 1, pp. 161-176, 2020.

[21] S. Liu, Q. Yu, L. Zhang, J. Xu, and Z. J. Jin, "Does intellectual capital investment improve financial competitiveness and green innovation performance? Evidence from renewable energy companies in China," Mathematical Problems in Engineering, vol. 2021, Article ID 9929202, 13 pages, 2021.

[22] A. Pulic, "VAIC ${ }^{\mathrm{TM}}$-an accounting tool for IC management," International Journal of Technology Management, vol. 20, no. 5-8, pp. 702-714, 2000.

[23] T. A. Stewart, Intellectual Capital. The New Wealth of Organizations, Doubleday, New York, NY, USA, 1997.

[24] N. Bontis, "Assessing knowledge assets: a review of the models used to measure intellectual capital," International Journal of Management Reviews, vol. 3, no. 1, pp. 41-60, 2001.

[25] L. Edvinsson and M. S. Malone, Intellectual Capital: Realizing Your Company's True Value by Finding its Hidden Brainpower, Harper Business, New York, NY, USA, 1997.

[26] K. E. Sveiby, The New Organizational Wealth: Managing and Measuring Knowledge-Based Assets, Berrett-Koehle, San Francisco, CA, USA, 1997.

[27] S. Nimtrakoon, "The relationship between intellectual capital, firms' market value and financial performance," Journal of Intellectual Capital, vol. 16, no. 3, pp. 587-618, 2015.

[28] F. Sardo, Z. Serrasqueiro, and H. Alves, "On the relationship between intellectual capital and financial performance: a panel data analysis on SME hotels," International Journal of Hospitality Management, vol. 75, pp. 67-74, 2018.

[29] R. Tiwari and H. Vidyarthi, "Intellectual capital and corporate performance: a case of Indian banks," Journal of Accounting in Emerging Economies, vol. 8, no. 1, pp. 84-105, 2018.

[30] H. Vidyarthi and R. Tiwari, "Cost, revenue, and profit efficiency characteristics, and intellectual capital in Indian Banks," Journal of Intellectual Capital, vol. 21, no. 1, pp. 1-22, 2019.

[31] J. Xu and B. Wang, "Intellectual capital performance of the textile industry in emerging markets: a comparison with China and South Korea," Sustainability, vol. 11, no. 8, p. 2354, 2019.

[32] J. Xu, Y. Shang, W. Z. Yu, and F. Liu, "Intellectual capital, technological innovation and firm performance: evidence from China's manufacturing sector," Sustainability, vol. 11, no. 19, p. 5328, 2019.

[33] J. Xu and J. Li, "The impact of intellectual capital on SMEs' performance in China," Journal of Intellectual Capital, vol. 20, no. 4, pp. 488-509, 2019.

[34] V. Costa, L. Silva, and L. Paula, "Intellectual capital and its impact on business performance: an empirical study of
Portuguese hospitality and tourism sector," Intangible Capital, vol. 16, no. 2, pp. 78-89, 2020.

[35] J. Xu and J. S. Li, "The interrelationship between intellectual capital and firm performance: evidence from China's manufacturing sector," Journal of Intellectual Capital, vol. 22, 2020.

[36] Y. Q. Lu, G. W. Li, Z. Luo, M. Anwar, and Y. J. Zhang, "Does intellectual capital spur sustainable competitive advantage and sustainable growth?: a study of Chinese and Pakistani firms," Sage Open, vol. 11, no. 1, Article ID 2158244021996702, 2020.

[37] N. Bontis, "Intellectual capital: an exploratory study that develops measures and models," Management Decision, vol. 36, no. 2, pp. 63-76, 1998.

[38] G. Roos and J. Roos, “Measuring your company's intellectual performance," Long Range Planning, vol. 30, no. 3, pp. 413-426, 1997.

[39] S. K. W. Chiu, K. H. Chan, and W. W. Y. Wu, "Charting intellectual capital performance of the gateway to China," Journal of Intellectual Capital, vol. 12, no. 2, pp. 249-276, 2011.

[40] M. C. Chen, S. J. Cheng, and Y. Hwang, "An empirical investigation of the relationship between intellectual capital and firms' market value and financial performance," Journal of Intellectual Capital, vol. 6, no. 2, pp. 159-176, 2005.

[41] Q. L. Kweh, W.-M. Lu, W.-K. Wang, and M.-H. Su, "Life insurance companies' performance and intellectual capital: a long-term perspective," International Journal of Information Technology \& Decision Making, vol. 13, no. 4, pp. 755-777, 2014.

[42] A. Bhatia and K. Aggarwal, "Intellectual capital and financial performance of Indian software industry: a panel data analysis," Pacific Business Review International, vol. 7, no. 8, pp. 33-43, 2015.

[43] V. Dženopoljac, S. Janoševic, and N. Bontis, "Intellectual capital and financial performance in the Serbian ICT industry," Journal of Intellectual Capital, vol. 17, no. 2, pp. 373-396, 2016.

[44] A. Meles, C. Porzio, G. Sampagnaro, and V. Verdoliva, "The impact of the intellectual capital efficiency on commercial banks performance: evidence from the US," Journal of Multinational Financial Management, vol. 36, pp. 64-74, 2016.

[45] N. Ozkan, S. Cakan, and M. Kayacan, "Intellectual capital and financial performance: a study of the Turkish Banking Sector," Borsa Istanbul Review, vol. 17, no. 3, pp. 190-198, 2017.

[46] N. Smriti and N. Das, "Impact of intellectual capital on business performance: evidence from Indian pharmaceutical sector," Polish Journal of Management Studies, vol. 15, no. 1, pp. 232-243, 2017.

[47] X.-L. Xu, X.-N. Yang, L. Zhan, C. K. Liu, N.-D. Zhou, and $\mathrm{M} . \mathrm{Hu}$, "Examining the relationship between intellectual capital and performance of listed environmental protection companies," Environmental Progress \& Sustainable Energy, vol. 36, no. 4, pp. 1056-1066, 2017.

[48] L. A. M. Chowdhury, T. Rana, M. Akter, and M. Hoque, "Impact of intellectual capital on financial performance: evidence from the Bangladeshi textile sector," Journal of Accounting \& Organizational Change, vol. 14, no. 4, pp. 429-454, 2018.

[49] J. Xu and B. H. Wang, "Intellectual capital and financial performance of Chinese agricultural listed companies," Custos e Agronegocio On Line, vol. 15, no. 1, pp. 273-290, 2019. 
[50] H. Yao, M. Haris, G. Tariq, H. M. Javaid, and M. A. S. Khan, "Intellectual capital, profitability, and productivity: evidence from Pakistani financial institutions," Sustainability, vol. 11, no. 14, p. 3842, 2019.

[51] D. Bansal and S. Singh, "Impact of intellectual capital on financial performance of the Indian software sector," AsiaPacific Management Accounting Journal, vol. 15, no. 1, pp. 67-95, 2020.

[52] P. S. Kasoga, "Does investing in intellectual capital improve financial performance? Panel evidence from firms listed in Tanzania DSE," Cogent Economics \& Finance, vol. 8, no. 1, Article ID 1802815, 2020.

[53] K. Gupta and T. V. Raman, "Influence of intellectual capital on performance," International Journal of Human Capital and Information Technology Professionals, vol. 12, no. 2, pp. 53-71, 2021.

[54] E. Neves and C. Proença, "Intellectual capital and financial performance: evidence from Portuguese banks," International Journal of Learning and Intellectual Capital, vol. 18, no. 1, pp. 93-108, 2021.

[55] K. Tandon, H. Purohit, and D. Tandon, "Measuring intellectual capital and its impact on financial performance: empirical evidence from CNX nifty companies," Global Business Review, vol. 17, no. 4, pp. 980-997, 2016.

[56] V. Dzenopoljac, C. Yaacoub, N. Elkanj, and N. Bontis, "Impact of intellectual capital on corporate performance: evidence from the Arab region," Journal of Intellectual Capital, vol. 18, no. 4, pp. 884-903, 2017.

[57] L. T. Poh, A. Kilicman, and S. N. I. Ibrahim, "On intellectual capital and financial performances of banks in Malaysia," Cogent Economics \& Finance, vol. 6, no. 1, Article ID 1453574, 2018.

[58] G. K. Oppong and J. K. Pattanayak, "Does investing in intellectual capital improve productivity? Panel evidence from commercial banks in India," Borsa Istanbul Review, vol. 19, no. 3, pp. 219-227, 2019.

[59] N. Smriti and N. Das, "The impact of intellectual capital on firm performance: a study of Indian firms listed in COSPI," Journal of Intellectual Capital, vol. 19, no. 5, pp. 935-964, 2018.

[60] T. Andreeva and T. Garanina, "Do all elements of intellectual capital matter for organizational performance? Evidence from Russian context," Journal of Intellectual Capital, vol. 17, no. 2, pp. 397-412, 2016.

[61] M. Alipour, "The effect of intellectual capital on firm performance: an investigation of Iran insurance companies," Measuring Business Excellence, vol. 16, no. 1, pp. 53-66, 2012.

[62] S. Soriya and K. P. Narwal, "Intellectual capital performance in Indian banks: a panel data analysis," International Journal of Learning and Intellectual Capital, vol. 12, no. 2, pp. 103-121, 2015.

[63] U. L. Onyekwelu, J. I. Okoh, and F. C. Iyidiobi, "Effect of intellectual capital on financial performance of Banks in Nigeria," European Journal of Accounting, Auditing and Finance Research, vol. 5, no. 2, pp. 28-57, 2017.

[64] W. Barkat, L.-S. Beh, A. Ahmed, and R. Ahmed, "Impact of intellectual capital on innovation capability and organizational performance: an empirical investigation," Serbian Journal of Management, vol. 13, no. 2, pp. 365-379, 2018.

[65] K. Gupta, S. Goel, and P. Bhatia, "Intellectual capital and profitability: evidence from Indian pharmaceutical sector," Vision: The Journal of Business Perspective, vol. 24, no. 2, pp. 204-216, 2020.
[66] X. L. Xu, J. Li, D. Wu, and X. Zhang, “The intellectual capital efficiency and corporate sustainable growth nexus: comparison from agriculture, tourism and renewable energy sector," Environment, Development and Sustainability, vol. 24, 2021.

[67] M. Malinowska-Olszowy, "Importance of intellectual capital in enterprise growth, with special emphasis on the textile and clothing industry in Poland," Fibres \& Textiles in Eastern Europe, vol. 20, no. 5, pp. 10-15, 2012.

[68] J. Woiceshyn and P. Eriksson, "How innovation systems in Finland and Alberta work: lessons for policy and practice," Innovation, vol. 16, no. 1, pp. 19-31, 2014.

[69] F. Liu, K. Park, and U. Whang, "Organizational capabilities, export growth and job creation: an investigation of Korean SMEs," Sustainability, vol. 11, no. 14, p. 3986, 2019.

[70] Y. Z. Lu, Z. R. Tian, G. A. Buitrago, S. W. Gao, Y. J. Zhao, and S. Zhang, "Intellectual capital and firm performance in the context of venture-capital syndication background in China," Complexity, vol. 2021, Article ID 3425725, 17 pages, 2021.

[71] A. E. Bayraktaroglu, F. Calisir, and M. Baskak, "Intellectual capital and firm performance: an extended VAIC model," Journal of Intellectual Capital, vol. 20, no. 3, pp. 406-425, 2019.

[72] Y. S. Ni, Y.-R. Cheng, and P. Y. Huang, "Do intellectual capitals matter to firm value enhancement? Evidences from Taiwan," Journal of Intellectual Capital, vol. 22, no. 4, pp. 725-743, 2021.

[73] K. Phusavat, N. Comepa, A. Sitko-Lutek, and K. B. Ooi, "Interrelationships between intellectual capital and performance empirical examination," Industrial Management \& Data Systems, vol. 111, no. 5-6, pp. 810-829, 2011.

[74] R. G. Ahangar, "The relationship between intellectual capital and financial performance: an empirical investigation in an Iranian company," African Journal of Business Management, vol. 5, no. 1, pp. 88-95, 2011.

[75] S. Janosevic and V. Dzenopoljac, "Impact of intellectual capital on financial performance of Serbian companies," Actual Problems of Economics, vol. 133, pp. 554-564, 2012.

[76] N. Bontis, S. Janošević, and V. Dženopoljac, "Intellectual capital in Serbia's hotel industry," International Journal of Contemporary Hospitality Management, vol. 27, no. 6, pp. 1365-1384, 2015.

[77] K. Pal and S. Soriya, "IC performance of Indian pharmaceutical and textile industry," Journal of Intellectual Capital, vol. 13, no. 1, pp. 120-137, 2012.

[78] V. Slvalogathasan and X. B. Wu, "Impact of organization motivation on intellectual capital and innovation capability of the textile and apparel industry in Sri Lanka," International Journal of Innovation Science, vol. 7, no. 2, pp. 153-165, 2015.

[79] T. J. Andersen and A. H. Segars, "The impact of IT on decision structure and firm performance: evidence from the textile and apparel industry," Information \& Management, vol. 39, no. 2, pp. 85-100, 2011.

[80] Y. Ogai, Y. Matsumura, Y. Hoshino, T. Yasuda, and K. Ohkura, "Centralized business-to-business networks in the Japanese textile and apparel industry: using network analysis and an agent-based model," Journal of Robotics and Mechatronics, vol. 31, no. 4, pp. 546-557, 2019.

[81] J. Su and V. B. Gargeya, "Supplier selection in small- and medium-sized firms," American Journal of Business, vol. 31, no. 4, pp. 166-186, 2016.

[82] H. L. Lee, "Aligning supply chain strategies with product uncertainties," California Management Review, vol. 44, no. 3, pp. 105-119, 2002. 
[83] N.-M. T. Nong, P. T. Ho, and P. T. Ho, "Criteria for supplier selection in textile and apparel industry: a case study in vietnam," The Journal of Asian Finance, Economics and Business, vol. 6, no. 2, pp. 213-221, 2019.

[84] M. Malinowska-Olszowy, "The choice of appropriate tools for measuring intellectual capital as a determinant of success with special emphasis on the textile and clothing market," Autex Research Journal, vol. 13, no. 4, pp. 122-127, 2013.

[85] T.-N. Le and C.-N. Wang, "The integrated approach for sustainable performance evaluation in value chain of Vietnam textile and apparel industry," Sustainability, vol. 9, no. 3, p. 477, 2017.

[86] A. Gavranovic, "How to deal with new challenges? Economic, technological and social aspects of the textile and clothing industry," Textile \& Leather Review, vol. 1, no. 1, pp. 29-33, 2018. 